\title{
EDITORIAL: EU COHESION POLICY AND DOMESTIC TERRITORIAL GOVERNANCE. WHAT CHANCES FOR CROSS-FERTILIZATION?
}

\author{
Giancarlo Cotella (D) \\ Interuniversity Department of Regional and Urban Studies and Planning, Politecnico di Torino \\ 39 Viale Mattioli, 10125 Torino: Italy \\ giancarlo.cotella@polito.it
}

\begin{abstract}
Territorial governance is an extremely heterogeneous activity. Each European country is characterised by a complex system of legal acts, tools, discourses and practices that had consolidated through time, as a consequence of peculiar path-dependent processes. At the same time, since more than 30 years the European Union is developing territorially relevant actions and interventions, ultimately aiming at achieving the economic, social and territorial cohesion of the continent. The mutual relations entangling domestic and supranational territorial governance remain unclear: on the one hand, the European Union is required to produce a framework for delivering its policies that is flexible enough to accommodate domestic differences; on the other hand, domestic territorial governance and spatial planning systems should adapt in order to allow room for cross-fertilization with supranational interventions. This contribution builds on the evidence collected by the research project ESPON COMPASS to frame and explore this issue. In doing so, it serves as an introduction for this special issue that, in the following contributions, presents a number of concrete examples of interaction between EU spatial policies and domestic territorial governance and spatial planning.
\end{abstract}

Keywords: EU cohesion policy, territorial governance, spatial planning, cross-fertilization, ESPON.

\section{Introduction}

Since the industrial revolution, raising urbanisation rates, increases in personal wealth and car ownership, higher expectations regarding housing quality and the movement of population away from agriculture towards the industrial and services sectors have increased development pressures dramatically. The impact of these phenomena have been such that legislation has been introduced in each European country to empower public authorities to monitor and control territorial development and prepare plans, identifying what types of development will be permitted and where they would be most appropriate. This happened at different times in different countries from the late nineteenth century onwards, depending on political attitudes to the acceptability of such powers, which may be regarded as infringing individual rights to exploit private property, and diverse perceptions of the value of planning in different contexts. Also the European Union 
(EU) has had an implicit territorial agenda since its inception. Since the late 1980s, the increasing need to consider the spatial impacts of sectorial spending programmes fostered the development of a heterogeneous set of spatial planning concepts, tools and processes at the continental scale. A EU territorial governance framework progressively consolidated, attracting the attention of academics and practitioners. Why the EU had necessity to intervene in spatial planning issues and how, the lack of formal competences notwithstanding, this is currently possible and even welcome by European countries are indeed not idle questions. Processes and practices promoted at the EU level have triggered a complex mix of intended and unintended effects in national territorial governance and spatial planning systems. This led, among others, to a progressive mutual learning among domestic spatial planning traditions and to a renewal of practices and institutions in most countries. However, domestic territorial governance and EU policies often proceed on parallel tracks, limiting synergy and cross-fertilization.

Focusing on unfolding and fleshing out the above elements, this contribution serves as introduction to the present special issue, that explores the actual chances for cross-fertilization between domestic territorial governance and EU policies on the basis of a number of case studies. It does so building on the evidence gathered by the ESPON COMPASS project and, in particular, on a detailed study of the interaction between EU cohesion policy and national territorial governance and spatial planning on the ground. The paper is structured in five sections. After this brief introduction, it discusses the complex landscape for territorial governance and spatial planning in Europe, on the basis of over thirty years of comparative research on the matter. It then gives account of the evolution and consolidation of a EU territorial governance framework, as a direct emanation of the economic, social and territorial cohesion objectives. Section four focuses on the interaction between domestic and supranational territorial governance, and on the processes of Europeanization that triggers as a consequence. Finally, section five guides the reader through the contributions that compose this special issue, in an overall reflection on the actual chances for cross-fertilization between the EU and the member states in the field of territorial governance.

\section{Territorial governance and spatial planning in the European countries}

Territorial governance and spatial planning activities occur within frameworks of legally established objectives, tools, and procedures which, in modern states, are usually derived from fundamental constitutional rights (Janin Rivolin 2012). So, territorial governance and spatial planning 'systems' (Healey \& Williams 1993; Newman \& Thornley 1996; CEC 1997; Larsson 2006; Janin Rivolin 2008, 2012; Nadin \& Stead 2008; Stead \& Cotella 2011a, 2011b) allow and rule, in various ways in all countries and regions of the world, the multiple and complex processes of vertical (between policy levels) and horizontal (between policy sectors and between public and private subjects) interactions that address the spatial organization of social life. They are dynamic objects, subject to continuous change as a consequence of a range of drivers to which Europe's domestic contexts are variously responding. These drivers include globalization, sustainable development, economic reforms and demographic change, all of which are helping to shape national (and sub-national) systems. Moreover, new needs of spatial reorganization driven by the reshaping of institutional frameworks, such as those occurring through European integration as well as the worldwide re-scaling process of relationships between territory, public authority and individual rights, are additional triggers 
of change almost everywhere (Swyngedouw 2000; Sassen 2006; ESPON 2007). In this light, we can agree overall with Healey and Williams when they argue that the heterogeneity that characterises the European continent on the matter is the result of a range of related issues such as "the specific histories and geographies of particular places, and the way these interlock with national [and international] institutional structures, cultures and economic opportunities" (1993: 716).

The great diversity to be found within a wide number of systems in constant change has been increasingly recognised as a potential source of innovation and learning, as it is reflected by the vast academic literature that, since the end of the 1980s, had attempted to analyse and compare them (Nadin \& Stead 2008). Whereas most studies limited themselves to compare a small number of countries, a number of them attempted larger scale comparisons (Table 1). These activities started by focussing on the exploration of the differences in legal and administrative families (Davies et al. 1989; Healey \& Williams 1993; Newman \& Thornley 1996; Balchin et al. 1999), in so doing providing insights into broad similarities and differences in planning between countries, at the same time not being able to fully reflect the variety that characterizes territorial governance and spatial planning in different places and times. This limitation was partially overcome by the "EU Compendium of Spatial Planning Systems and Policies" (CEC 1997), the first comparative spatial planning study to be commissioned by a supranational policy institution. The document also starts its comparison from legal and administrative elements but also addresses six other relevant variables: (i) the scope of the system in terms of policy topics covered; (ii) the extent of national and regional planning; (iii) the locus of power and competences between central and local government; (iv) the relative roles of public and private sectors; (v) the maturity of the system or how well it is established in government and public life and (vi) the apparent distance between expressed goals for spatial development and outcomes. Building on these variables, it explains the variation of systems by developing four 'ideal types' of spatial planning traditions - namely 'regional economic', 'comprehensive integrated', 'land use management', and 'urbanism' (CEC 1997: 36-37).

Table 1. Main comparative studies on spatial planning systems in Europe

\begin{tabular}{|c|c|c|c|c|c|}
\hline $\begin{array}{l}\text { Davies et al. } \\
\text { (1989) }\end{array}$ & - & $\begin{array}{l}\text { Common law } \\
\text { England }\end{array}$ & - & $\begin{array}{l}\text { Napoleonic } \\
\text { codes } \\
\text { DK, DE, FR, NL }\end{array}$ & - \\
\hline $\begin{array}{l}\text { Newman \& } \\
\text { Thornley } \\
(1996)\end{array}$ & $\begin{array}{l}\text { Nordic } \\
\text { DK, FI, SE }\end{array}$ & $\begin{array}{l}\text { British } \\
\text { IE, UK }\end{array}$ & $\begin{array}{l}\text { Germanic } \\
\text { AT, DE }\end{array}$ & $\begin{array}{l}\text { Napoleonic } \\
\text { BE, FR, IT, LU, } \\
\text { NL, PT, ES } \\
\end{array}$ & - \\
\hline CEC (1997) & $\begin{array}{l}\text { Comprehensive } \\
\text { integrated } \\
\text { AT, DK, FI, DE, } \\
\text { NL, SE }\end{array}$ & $\begin{array}{l}\text { Land use } \\
\text { regulation } \\
\mathrm{IE}, \mathrm{UK} \\
(+\mathrm{BE}) \\
\end{array}$ & - & $\begin{array}{l}\text { Regional } \\
\text { economic } \\
\text { FR, PT (+ DE) }\end{array}$ & $\begin{array}{l}\text { Urbanism } \\
\text { GR, IT, ES } \\
\text { (+PT) }\end{array}$ \\
\hline $\begin{array}{l}\text { ESPON } \\
\text { Project 2.3.2 } \\
\text { Farinós Dasi } \\
(2007)\end{array}$ & $\begin{array}{l}\text { Comprehensive } \\
\text { integrated } \\
\text { AT, DK, FI, NL, SE, } \\
\text { DE (+ BE, FR, IE } \\
\text { LU, UK) } \\
\text { BG, EE, HU, LV, LT } \\
\text { PL, RO, SL, SV }\end{array}$ & $\begin{array}{l}\text { Land use } \\
\text { regulation } \\
\mathrm{BE}, \mathrm{IE}, \mathrm{LU}, \\
\text { UK (+ PT, ES) } \\
\mathrm{CY}, \mathrm{CZ}, \mathrm{MT}\end{array}$ & - & $\begin{array}{l}\text { Regional } \\
\text { economic } \\
\text { FR, DE, PT } \\
\text { (+ IE, SE, UK) } \\
\text { HU, LV, LT, SK }\end{array}$ & $\begin{array}{l}\text { Urbanism } \\
\text { GR, IT, ES } \\
\text { CY, MT }\end{array}$ \\
\hline
\end{tabular}

Source: adapted from Nadin \& Stead (2008: 38). 
Through time, a number of comparative studies built on the methodological foundations laid by this Compendium (e.g. Böhme 2002; Othengrafen 2010). The most extensive of them, the ESPON Project 2.3.2 on the "Governance of Territorial and Urban Policies" (ESPON 2007), uses the Compendium's four ideal types to compare as many as 29 countries' territorial governance and spatial planning systems, and to explore how they changed over time. The project uses variables on administration type, distribution of competences, decentralisation and devolution, inter-municipal cooperation, all cross-tabulated with other variables including the constitutional structure and central-local relationships to provide a complex classification of formal territorial governance arrangements.

Despite the heterogeneity of the results, the Compendium and the subsequent studies have helped in both the understanding of variation in approaches to territorial governance and planning and in developing the methodology for comparison. These methodological advances have been the core business of the working group on comparative spatial planning research instituted by the Akademie für Raumforschung und Landesplanung (the German Academy for Spatial Research and Planning). The results of its activities are collected in a special issue of "Planning Practice \& Research" (Nadin 2012), and provide extensive commentary on comparative planning methodology, including the recommendation to considering planning as an 'institutional technology' (Janin Rivolin 2012: 69-73). More in detail, the 'institutional technology' approach considers territorial governance and spatial planning systems as continuously shaped by social conventions, particularly concerning rights over land. It aims at overcoming any separation between the formal institutions of the system (i.e. rules and laws) and 'planning cultures', i.e. the concrete practices and mechanisms which determine ways of planning, and provides a unified analytical framework for the comparison of territorial governance and spatial planning, as well as to explain how they are influenced by EU policies (Cotella \& Janin Rivolin 2011, 2015).

This approach sets the ground for the ESPON COMPASS research (ESPON \& TU Delft 2018). Representing the first comprehensive comparative analysis of territorial governance and spatial planning in Europe since the publication of the Compendium, the project recognizes the value of updating knowledge of territorial governance and spatial planning systems because of the potential synergy with EU sectorial policies in a place-based approach (Barca 2009). Overall, the project compares territorial governance and spatial planning in 32 European countries (the $28 \mathrm{EU}$ member states plus 4 ESPON partner countries), and differs from previous studies in that the accent is on identifying trends in reforms from 2000 to 2016. It seeks to give reasons for these changes with particular reference to EU directives and policies, and to identify good practices for the cross-fertilisation of spatial development policies with EU cohesion policy, this being the very focus of this special issue.

The evidence collected through the project shows how territorial governance and spatial planning in Europe has grown more and more fragmented, making it hard to individuate typologies or clusters of countries as it has been done by previous studies. Whereas all European countries control the right to develop or change the use of land using a hierarchy of instruments involving multiple levels of government, their detailed arrangements are however exceedingly varied. The general understanding of planning is as a process of steering development or the use of space, and managing competing interests over land so as to balance development with the protection of land in the public interest. At the same time, sustainable development, environmental protection, citizen engagement, infrastructure and economic growth as well as promoting EU territorial cohesion are commonly mentioned objectives. Moreover, the project shows how, since 2000, there have been considerable shifts in the allocation of competences among levels of government (Fig. 1). The most common trend is decentralisation from national to sub-national and local levels, but a small number of countries are increasing powers at the national level. There is also much reporting of a rescaling of planning competences in 'functional planning regions' to address 
the reality of environmental, commuting, economic and other flows across borders. When it comes to the heterogeneity spatial planning instruments, the project has identified as many as 251 types, active at various territorial levels and often serving multiple functions. Whilst the strategic function tends to dominate at the national level and the regulative at the local level, this should not be taken for granted. Although planning is often criticised for its rigid regulatory approaches, visioning and strategy-making activities are increasing.

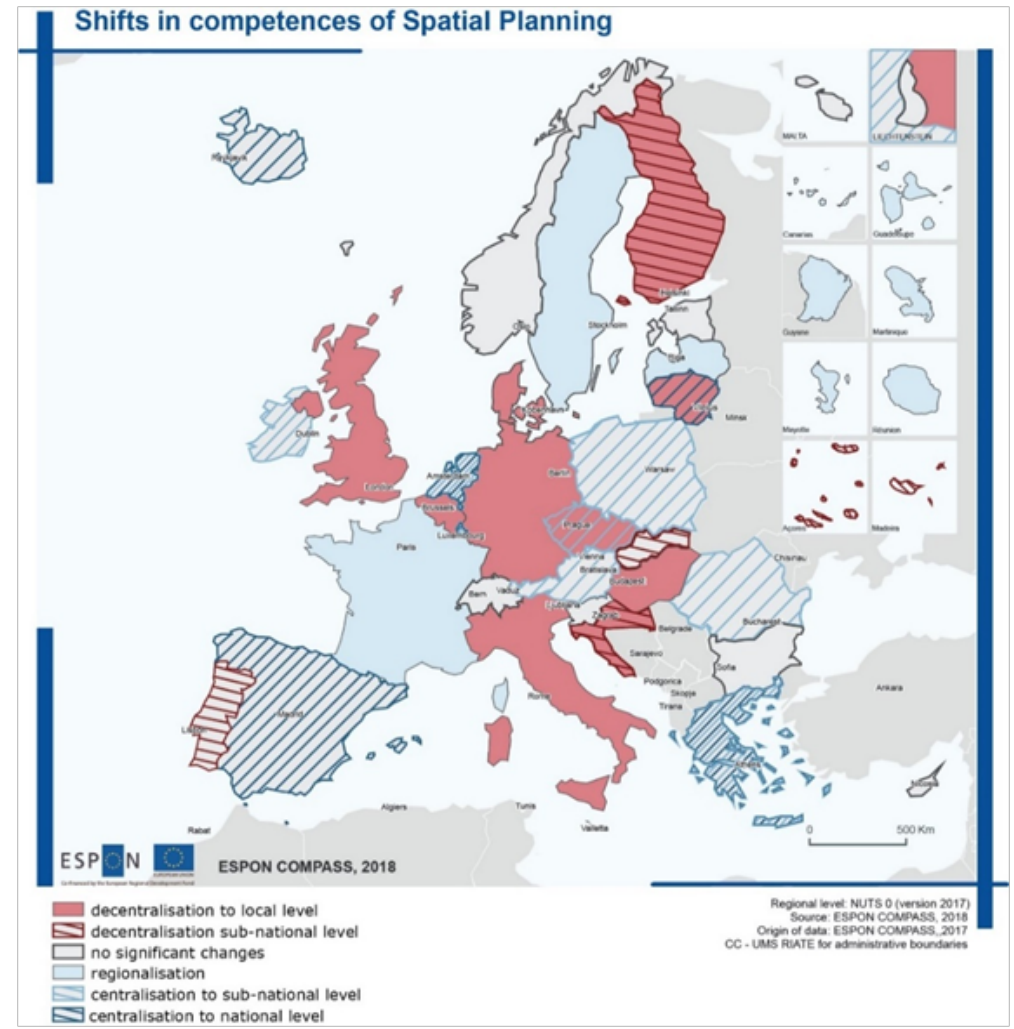

Figure 1. Shifts in territorial governance and spatial planning competences in the period 2000-2016 Source: ESPON \& TU Delft (2018: 19).

The overall picture is of territorial governance and spatial planning activities evolving to address weaknesses and to better address contemporary issues. There is little evidence of 'deregulation' in the formal structure of planning systems, but rather multiple innovations in the form of governance structures, instruments and procedures. Whereas, in general terms, the various spatial planning instruments continue to have a more or less direct influence on guiding and controlling spatial development, there exists however countries which have experienced difficulties since the 2008 financial crisis, and where the influence of planning has declined. Finally, most countries reported a growing relevance of the EU territorial governance framework. However, as it will be further presented in the following paragraphs, a lack of integration of the EU policies within domestic territorial governance is still lamented. 


\section{The European Union's quest for social, economic and territorial cohesion}

The progressive consolidation of EU territorial governance is not a direct outcome of the EU political will, rather the result of a number of more or less coherent responses to the development challenges that progressively interested Europe since the second half of the twentieth century (Adams et al. 2011). Whereas the EU has had a spatial agenda since its inception, its claims on territorial development matters were not satisfied until the second half of the 1980s (Williams 1996; Faludi 2001), when the progression of the European Economic Integration led to the development of some institutional preconditions to allow the EU to limit the unbalancing trends that could have resulted from it. As a consequence, despite the reluctance of some member states, the economic and social cohesion objective was introduced in the Single European Act in 1986, in practice affirming the need for a supranational action on territorial development as the political condition for integration (Williams 1996; Dühr et al. 2010). In the wake of the new objective, the structural funds were reformed in 1988, giving birth to the EU cohesion policy. At the same time, a complex discursive process was kicked-off that, in ten years' time, would have led to the publication of the "European Spatial Development Perspective" (CEC 1999), by some labelled European spatial planning's proudest achievement (Faludi 2001: 245).

During the preparation of the ESDP in the 1990s, EU territorial governance gained momentum; it was no longer only a framework for debate but an arena for policy-making. A few years after the document's publication, the terms European spatial planning and spatial development were increasingly replaced by 'territorial cohesion', an objective that progressively carved its way into the acquis communautaire. This formally occurred with the ratification of the Treaty of Lisbon in 2009: since then, territorial cohesion, alongside with its economic and social dimensions, figures as a shared competence between the EU and its member states, in so doing allowing for a further consolidation of EU territorial governance. As argued by the EU ministers responsible for spatial planning in the member states, the latter represents "a special and growing challenge", which implies the necessity of "integrating the territorial dimension into EU and National Policies, and not creating a top-down and separate EU Territorial Policy" (DE Presidency 2007: 8-9).

Despite all efforts, however, the exact boundaries of EU territorial governance remain rather blurred. As already intuited by Doria et al. more than a decade ago (2006), the latter resembles a hologram, an object composed by many different dimensions, each containing the almost total amount of information to describe it without being, in itself, self-sufficient. This is more clear when one considers that EU territorial governance originates from, and is composed by several policy fields, that very much differ in relation to their contents as well as their forms of intervention. To further share some light on this picture, Purkarthofer (2018) builds on Vedung et al. (1998) to define EU policy-making as working through "sticks, carrots and sermons" (2018: 20-21). This threefold classification results in a trichotomy of policy interventions - rules and regulations; economic means; discourse and information - each type determining a different relationship of governor and governee. Rules and regulations oblige the governee to do what the governor demands. Economic means do not demand a specific action from the governee, however, compliance with a suggested action results in gain of material. Discourse and information, in turn, do not oblige the governee to act in a specific way, but shape and frame attention as they affect what is considered worthwhile of knowing. 
For each of these categories, a multitude of examples can be found in EU policy-making (Table 2). As far as the development of rules and regulations is concerned, the EU is allowed to act only in those fields where it detains competence either exclusively or jointly with its member states. Among them, environmental regulations have been developed since the 1970s, leading to an exponential increment of EU environmental directives and regulations (as for instance those running under the Nature 2000 framework, or those concerning Environmental Impact Assessment and Strategic Environmental Assessment). At the same time, relevant regulations that have an impact over spatial planning were produced in the field of energy (Cotella \& Crivello 2016; Cotella et al., 2016a;Valkenburg \& Cotella 2016 ), competition (e.g. the directive on public procurement, Colomb \& Santinha 2014) and, in more recent years, maritime spatial planning (EC 2014; Walsh \& Kannen 2019).

When it comes to economic interventions, beside the mainstream EU cohesion policy programming, the EU has progressively put into place a varying number of initiatives to finance territorial development in the member states. These initiatives are characterised by a rather heterogeneous scope. A first group is represented by those tools insisting on urban development, i.e. the first Urban Pilot programmes, the URBAN Community Initiative and, more recently, the Integrated Territorial Investments (Cotella 2019). Similarly, another strand of EU spatial policies focuses on territorial cooperation and, through time, led to the consolidation of the INTERREG Community Initiative into the mainstream European Territorial Cooperation objective (Dühr et al. 2007). Also the development of rural areas has been through time fallen under the scope of the EU policies and actions, at first through the LEADER Community Initiatives and, more recently, thanks to the so-called Community Led Local Developments (Servillo \& De Bruijn 2018). Finally, an important share of resources has been devoted to the development of transport infrastructure and the completion of the so-called Trans-European Transport Networks.

Table 2. Examples of EU territorial governance, a trichotomy of policy interventions

\begin{tabular}{|c|c|}
\hline Type of policy intervention & Examples \\
\hline Regulatory: regulations and directives & $\begin{array}{l}\text { - Environmental Impact Assessment } \\
\text { - Strategic Environmental Assessment } \\
\text { - State Aid Guidelines } \\
\text { - Nature } 2000 \text { (Birds and Habitats Directives) } \\
\text { - Urban Waste Water Treatment Directives } \\
\text { - Energy Directives } \\
\text { - Maritime Spatial Planning Directive }\end{array}$ \\
\hline Remunerative: funds and subsidies & $\begin{array}{l}\text { - EU Cohesion Policy } \\
\text { - EU Rural Development Policy (and LEADER Community Initiative) } \\
\text { - European Territorial Cooperation } \\
\text { - Urban Community Initiative } \\
\text { - Integrated Territorial Investments } \\
\text { - Community Led Local Developments } \\
\text { - Trans-European Transport Networks }\end{array}$ \\
\hline $\begin{array}{l}\text { Discursive: strategic policy papers, } \\
\text { concepts, evidence }\end{array}$ & $\begin{array}{l}\text { - European Spatial Development Perspective } \\
\text { - EU Territorial Agenda } \\
\text { - EU Territorial Agenda } 2020 \\
\text { - Lisbon and Gothenburg Strategies } \\
\text { - Europe } 2020 \text { Strategy } \\
\text { - EU Urban Agenda } \\
\text { - EU Macro-regional Strategies } \\
\text { - ESPON results and recommendations }\end{array}$ \\
\hline
\end{tabular}

Source: author's own elaboration. 
As far as the development of discourse and information is concerned, a number of policy documents followed the ESDP. A first "Territorial Agenda of the European Union" (DE Presidency 2007) was published in 2007, shortly followed by the Territorial Agenda 2020 (HU Presidency 2011), that is currently under revision by the Network of Territorial Cohesion Contact Points . However, none of these intergovernmental documents had been received as enthusiastically as the ESDP by planners across Europe. At the same time, a series of mainstream development strategies have been approved by the European Council, starting with the Lisbon and Gothenburg Strategies at the edge of the new millennium and eventually leading to the publication of the Europe 2020 Strategy. A number of other discursive documents complete the framework, as all the document framing the so-called EU urban policy (Cotella 2019), the growing number of strategies proposed by the Commission for selected macroregional areas (Ganzle \& Kern 2015), and the stock of evidence, information and policy recommendations that has been produced by the ESPON programme since its institution in 2001 (Prezioso 2007).

The three types of policy interventions cannot be viewed as entirely independent from each other. Strategies and funds often emphasise the same objectives, as can be seen for instance in the Territorial Agenda 2020 strategy and the structural funds during the 2007-2013 programming period, both focusing on smart, sustainable and inclusive growth. Similarly, non-binding strategies are often - though not always - the first step towards the extension of EU competences and the enactment of binding regulations. The rules for the disbursement of funds and subsidies are stipulated in binding regulations. The same actors are involved in the preparation of all types of policies, suggesting a certain degree of convergence regarding themes, objectives and terminology. While it might be flawed to view all these policy interventions as planning policies, they nonetheless affect spatial development and territorial governance, thus making it important to take them into account when mapping the EU's effects on planning. The actual mechanisms through which EU territorial governance exert an impact on domestic territorial governance and spatial planning will be further detailed in the following section.

\section{Towards a progressive Europeanization of territorial governance?}

Europeanization is not a concept solely relating to the field of planning studies. Born in the cradle of policy studies concerning the EU integration process, it builds on the evidence of co-evolution and mutual adaptation of the institutional contexts involved, as a meaningful component of integration itself. In spite of the many definitions and applications (see for instance: Olsen 2002; Featherstone \& Radaelli 2003; Radaelli 2004; Bruno et al. 2006), in its broadest sense Europeanization describes a complex process of institutionalisation that includes both the increasing impacts of Europe on national polities, policies and politics (Knill \& Lehmkuhl 1999; Borzel \& Risse 2000) and the simultaneous domestic influences 'uploaded' at the EU level (Wishlade et al. 2003; Salgado \& Woll 2004). It also includes forms of 'horizontal' influence between member states, whereas the EU operates as a platform for mutual exchange and policy transfer (Lenschow 2006, Cotella et al. 2016b).

The concept of Europeanization has progressively entered the field of planning studies as a consistent approach for interpreting the outcomes resulting from the progressive consolidation of EU territorial governance. As presented above, a general consequence of the progressive consolidation 
of a EU territorial governance framework is that "planning for Europe is conditioned and at the same time changes the context (or system environment) of planning in Europe", a phenomenon that can be investigated in terms of 'Europeanization of spatial planning' (Böhme \& Waterhout 2008: 226; Stead \& Cotella 2011a, 2011b; Cotella \& Janin Rivolin 2011, 2015). When it comes to exploring the domestic impact of European policies, three mechanisms are commonly considered in literature concerning Europeanization: "First, and in its most 'explicit' form, European policy-making may trigger domestic change by prescribing concrete institutional requirements with which member states must comply; that is, EU policy 'positively' prescribes an institutional model to which domestic arrangements have to be adjusted. [...] Second, and somewhat more implicitly, [...] European influence is confined to altering domestic opportunity structures, and hence the distribution of power and resources between domestic actors. [...] Third, in its 'weakest' form, European policy [...] affects domestic arrangements even more indirectly, namely by altering the beliefs and expectations of domestic actors. [...] Hence, the domestic impact of European policies is primarily based on a cognitive logic" (Knill \& Lehmkuhl 1999:1-2). As far as territorial governance is concerned, these three mechanisms translates in as many 'downloading' influences concurring to the Europeanization of territorial governance and spatial planning - namely structural, instrumental and top-down discursive - depending on which is the prevailing driver in transforming governance, among the three groups presented in the section above (i.e. rules and regulations, economic means, discourse and information).

More in detail, the structural influence describes the logic of the so-called 'Community method' (Nugent 2006), according to which the EU treaties allow for the promulgation of EU legislation (regulations, directives and decisions) in established policy fields. Member states are consequently obliged to adjust their respective legislations according to the so-called 'transposition' process (Dühr et al. 2010: 149-157). This is potentially the most coercive mechanism of influence exerted by the EU on its member states, since it implies a 'legal conditionality', meaning that sanctions in case of non-compliance are usually envisaged. As far as territorial governance is concerned, the lack of a formal EU competence in the field of spatial policies and planning implies that this kind of influence is largely ineffective with regard to the whole operation of national planning systems (Janin Rivolin 2010). Some indirect impact is however visible whereas the EU legislation may concern sector policies that are somehow related to spatial planning, such as the environmental, energy and competition. It is interesting to note that, despite their universal validity in the EU context, these directives or decisions do not have a standardised impact on each member state. Rather, impacts and effects depend largely on the 'receiving context' and, more particularly, on the proximity / distance between EU and domestic rules, as well as on the 'reception capacity' of domestic structures.

The instrumental influence is addressed "to altering domestic opportunity structures, and hence the distribution of power and resources between domestic actors" (Knill \& Lehmkuhl 1999: 1), and its effectiveness is therefore based on forms of 'economic conditionality' rather than on legal power. The main example in this concern is provided by the EU structural funds, often defined "the pot of gold at the end of the rainbow" of European spatial planning (Williams 1996: 114), but an important role is also played by the other financial instruments and actions introduced in the section above. Through these are financial instruments, the EU invests an average of $80-90 \%$ of its annual budget to promote structural aid for economic and social purposes in member states. The so-called principle of 'additionality', establishing that EU resources have to be co-financed by domestic public or private stakeholders, ensures a high degree of domestic self-commitment to EU cohesion policy. In brief, the introduction of substantial and recursive 
incentives addressed overall to more 'cohesive' regional policy, to systematic territorial cooperation in cross-border and transnational contexts, and to widespread application of a EU standard of sustainable urban development has progressively modified the cost-benefit logics of domestic actors and stimulated variations in the established customs and routines relating to territorial governance practices. Crucial here is the engagement of local actors in complex processes of economic convenience and 'social learning' triggered by goals and means shared at the EU level (Schimmelfenning \& Sedelmeier 2005: 18-20). Domestic change in spatial planning under this kind of influence seems to occur ultimately according to a mixture of economic conditionality mechanisms and an interactive "socialization and collective learning process resulting in norm internalization and the development of new identities" (Borzel \& Risse 2000: 2).

The top-down discursive influence is embedded in a circular process of exchange of ideas and perspectives labelled as 'discursive integration' (Böhme 2002; Waterhout 2008). This concept has emerged from the specific domain of European spatial planning studies, especially in relation to the joint elaboration of the ESDP by the ministers responsible for spatial planning in the EU countries (Faludi \& Waterhout 2002). It denotes an "example of European integration by networking and policy discourses" that "can be successful when there are strong policy communities active at European and national levels and direct links between them" (Böhme 2002: III). A topdown dialogic influence may therefore occur whereas certain 'hegemonic concepts' prevail in this interactive process (Servillo 2010), which can alter beliefs and expectations of domestic actors according to forms of 'cognitive conditionality' (Radaelli 2004). Its possible effectiveness, however, is not strictly relegated in the policy arena of decision-makers, but can come also from a broader, increasing and much more articulated interactivity of 'territorial knowledge communities' developing in Europe (Adams et al. 2011). Overall, since changes in actors' preferences in each domestic context are this way based on persuasion, according to a 'logic of appropriateness' (March \& Olsen 1998), intensity and quality of domestic change depends particularly on the degree to which the EU discourse is appreciated as appropriate in terms of legitimacy, collective identity, values and norms. Arguably, even more than in previous types of influence, "the likelihood of integration between domestic and EU discourse increases the more that public policymakers have institutionalised relationships with epistemic communities that promote EU rules and the more that domestic structures are conductive to the influence of new ideas" (Schimmelfenning \& Sedelmeier 2005: 23).

In order to understand what changes in territorial governance and spatial planning systems may be attributed to the influence of the EU, the ESPON COMPASS project systematically explored how national territorial governance and spatial planning systems have been related, through time, to European territorial governance. The impact of EU rules and regulations - in the fields of environment, energy and competition in particular - has produced rather uniform impacts on domestic territorial governance and spatial planning and such influence has been increasing over time in almost all countries. The impact of EU economic means was more varied. EU cohesion policy is reported to have the highest influence; by contrast, other EU policy fields tend to have a moderate impact. The impact is generally geographically differentiated and appears, at least partly, correlated to the magnitude of financial resources delivered to each country. Finally, the impact of the EU discourse and information on domestic systems is highly differentiated, as it depends on the voluntary nature of the mechanisms behind this type of influence. EU mainstream development strategies are the most influential, having a direct impact on the development of EU policies and on funds distribution. Overall, Europeanization outcomes are highly differential and vary by country, by sector and over time, due to its 'filtering' through the numer- 
ous substantive and procedural differences among the national systems (Stead \& Cotella 2011a; ESPON \& TU Delft 2018). This ultimately points to the need for formal clarification, in institutional terms, of the role of domestic territorial governance and spatial planning systems with respect to European territorial governance and EU cohesion policy. As it will be introduced in the following section, and then further detailed in the contributions that composes this special issue, despite the existience of shared competences between the EU and the member states of 'economic, social and territorial cohesion', the search for synergies and cross-fertilization between EU and domestic territorial governance is still ongoing.

\section{In search for cross-fertilization: a roadmap for the reader}

One of the assumptions behind the ESPON COMPASS project is that territorial governance and spatial planning at national, sub-national and local levels offers a means to strengthen the combined impact of EU policies. This however requires a broader 'spatial planning approach' focussing on the horizontal and vertical coordination of the territorial impacts of policies and actions. As the gathered evidence suggests, however, in the majority of the member states EU spatial policies and domestic territorial governance continue to proceed rather autonomously one from the other. The six contributions collected in this special issues aim at shedding light on this matter, by presenting as many examples of how EU cohesion policy and domestic territorial governance and spatial planning interact in the practice. These examples show in more detail the variability of relationships between cohesion policy and spatial planning. Cohesion policy often has a direct impact on physical spatial development through funded projects, and thus there is a strong indirect connection with spatial planning, especially where spending is high. The connection is weaker where there is less funding for infrastructure projects. Where there are impacts, they may support domestic planning strategies and policies - as in the case of infrastructure projects promoting increased densities, or they may undermine planning where spending facilitates suburbanisation. Overall, the effectiveness of spatial planning in steering EU-funded investments varies and domestic territorial governnace does not seem well equipped to take on the task of steering such investments because of different timescales and priorities (ESPON \& TU Delft 2018).

The first contribution, authored by L. Smas and J. Lidmo explores the role played by Swedish regions as intersection and potential field for cross-fertilization between EU and domestic territorial governance. The article focuses on the vertical positioning of the regions from EU to the local level, and sectorial integration with other policy fields. The results show that spatial planning is practiced both through statutory planning and through soft planning. These practices, in different ways, coordinate sectorial policies i.e. transport infrastructure, regional development and spatial planning. The authors also argue that regions can function as multi-level coordinators; however, their focus mostly remain on local actors rather than on EU policies. The proposed examples illustrate difficulties not only of external coordination between different policy fields and organizations but also internally within organizations. At the same time, they hint that the organization of territorial governance within a given institutional arrangement is crucial for how regions might function as multi-level coordination organizations and policy arenas within spatial planning.

In the second contribution, É. Perger discusses the impact of the EU cohesion policy on planning and development activities in functional regions in the context of Hungary. It explores the legal and institutional background of functional regions and focuses upon present challenges 
concerning the management structures in territorial units crossing administrative borders. In doing so, it demonstrates that, despite the need for a place based, territorially sensitive and integrated approach has become one of the most highlighted issues over the last decade, the overall impacts of EU cohesion policy on planning and development activities in the country has been rather controversial, as it did not produce any significant contribution to the integrated territorial developments of regions crossing administrative borders. According to the author, the recent developments of the EU cohesion policy have led to controversial effect: on the one hand the EU legislation has provided more tools for integrated developments in functional regions; on the other hand, the thematic concentration and tight performance control have introduced less flexible, bureaucratic procedures. Since Hungarian functional regions do not fit into the general implementation structure, the central government increasingly takes concrete project-level decisions regarding the development in functional regions. In this situation, there is a high risk that local aspects and territorial coordination requirement would fade into the background.

S. Hans and K. Böhme explores the innovative features of territorial governance and spatial planning in Luxembourg in the third paper of the issue. They explain how, despite being relatively young, the territorial governance and spatial planning system of Luxembourg is used to digest and to distribute the socio-economic growth and push for a more polycentric territorial structure. This occurs through the development and implementation of a number of different instruments, that varies from traditional spatial planning tools to forward-thinking approaches, which give spatial planning in Luxembourg an innovative edge compared to other European countries. Among these forward-thinking approaches are e.g., national public participation processes, soft territorial cooperation or cross-border planning, that often integrates and exploits synergies with EU territorial governance funding instruments.

The contribution authored by T. Komornicki et al., focuses more in depth on the implementation of the EU cohesion policy in the regions of Poland in the programming period 2014-2020, aiming at unfolding the mutual interrelations between domestic spatial planning choices and the effectiveness of supranational policies. Overall, the paper presents the most important challenges, the adopted solutions and the effects of the implementation of EU funding programmes in Poland within three thematic areas (i.e. polycentricity and suburbanisation, transport infrastructure and accessibility and natural and cultural heritage). The authors clearly point out the basic planning conditions of policies implementation resulting from integration with the EU. They reflect upon the consequences of these conditions for territorial governance and for the implementation of cohesion policies, and argue that territorial governance is struggling with the punctuality of investments implemented with EU funds, partly due to the lack of a coherent vision of spatial and economic development of the region.

The fifth paper, by B. Williams and J. Varghese, explores the evolution of the Irish planning system and the impact of the EU cohesion policy aiming to reduce regional and social disparities within the EU with respect to recent developments in Ireland. The changing nature of the Irish planning system is presented as shifting from a market or local development led approach towards a more strategic regional and national approach. This trend has in part been influenced by EU policies, directives and initiatives with evidence of both difficulties and successful delivery of some major projects. The discussion is complemented by evidence from two case studies in the transportation area and interviews with key participants in the policy processes. Overall, the lessons from past Irish policy changes shows that a strong political commitment and dedicated resourcing is essential to support new directions in policy. The availability of EU funding and resources is both a necessity and a useful external reference framework within which strategic planning decisions for the regions of Ireland are adopted and implemented. 
Finally the contribution by Z. Pamer provides a comparative analysis of the activity and funding patterns of Central European cross-border cooperation programmes, with particular reference to the Slovenia-Austria and the Hungary-Croatia cooperations. The authors underlines how European territorial cooperation plays a key role in promoting Europeanization, which is especially important in case of Central Europe that is dominated by small national states. After presenting the premises for cross-border cooperation and a brief outline of the programmes, a quantified analysis is proposed, based on primary ex-post programme data and conduceted on LAU 2 level in order to show how different categories of the settlement structure contribute in terms of cooperation activity and absorption and how it is distributed between different types of beneficiary organisations. Overall the contribution shows how, due to recent public administration reforms, territorial governance structures in the countries at stake have become similar, and how this similarity reflects in terms of activity in cooperation projects and absorption of funding on different levels of the settlement structure.

The special issue is coherently concluded by a review of the new book authored by A. Faludi, "The Poverty of Territorialism. A Neo-Medieval View of Europe and European Planning" (Faludi 2018). Here J. Zaucha focuses on the alternative views of the EU presented by the book's author, as well as on the open-ended character of the European project, highlighting how the nature itself of the EU project requires to engage in continuous efforts to (re)conceptualize territorial governance and spatial planning both within and outside existing administrative containers.

\section{Acknowledgments}

The editor would like to express his gratitude to all the colleagues involved in the ESPON COMPASS project, for over two years of proactive exchange of knowledge over territorial governance and spatial planning in Europe and beyond.

\section{References}

Adams N., Cotella G., Nunes R. (eds.), 2012. Territorial development, cohesion and spatial planning: Building on EU enlargement. Routledge.

Balchin P., Sykora L., Bull G., 2002. Regional policy and planning in Europe. Routledge.

Barca F., 2009. An Agenda for a Reformed Cohesion Policy-Independent Report. European Commission, Brussels.

Böhme K., 2002. Nordic Echoes of European Spatial Planning. Stockholm: Nordregio.

Böhme K., Waterhout B., 2008. The Europeanization of planning. [in:] A. Faludi (ed.) European spatial research and planning. Lincold Institute of Land Policy, pp. 225-248.

Börzel T., Risse T., 2000. When Europe hits home: Europeanization and domestic change. European Integration Online Papers, vol. 4, no. 15.

Bruno I., Jacquot S., Mandin S., 2006. Europeanization through its instrumentation: benchmarking, mainstreaming and the open method of co-ordination ... toolbox or Pandora's box? Journal of European Public Policy, vol. 13, no. 4, pp. 519-536.

CEC - Commission of the European Communities, 1997. The EU Compendium of Spatial Planning Systems and Policies. Regional Development Studies, 28. Luxembourg: European Communities.

CEC - Commission of the European Communities, 1999. ESDP - European Spatial Development Perspective. Towards Balanced and Sustainable Development of the Territory of the EU. Approved 
by the Ministers responsible for Regional/Spatial Planning of the European Union. Luxembourg: European Communities.

Colomb C., Santinha G., 2014. European Union competition policy and the European territorial cohesion agenda: An impossible reconciliation? State aid rules and public service liberalization through the European spatial planning lens. European Planning Studies, vol. 22, no. 3, pp. 459-480.

Cotella G., Janin Rivolin U., 2015. Europeanizazione del governo del territorio: un modello analítico. Territorio, vol. 73, pp. 127-134.

Cotella G., 2019. The Urban Dimension of EU Cohesion Policy. [in:] Territorial Cohesion. Springer, pp. 133151.

Cotella G., Crivello S., 2016. The Macroregional Geopolitics of Energy Security: Towards a New Energy World Order? [in:] M. Gruning, P. Lombardi. Low-carbon Energy Security from a European Perspective. Elsevier Academic Press, pp. 81-108.

Cotella G., Crivello S., Karatayev M., 2016a. European Union energy policy evolutionary patterns. [in:] M. Gruning, P. Lombardi. Low-carbon Energy Security from a European Perspective. Elsevier Academic Press, pp.13-42.

Cotella G., Janin Rivolin U., 2011. Europeanization of spatial planning through discourse and practice in Italy. disP-The Planning Review, vol. 47, no. 186, pp. 42-53.

Cotella G., Janin Rivolin U., Santangelo M., 2016b. Transferring 'good' territorial governance across Europe: opportunities and barriers. [in:] L. Van Well, P. Schmitt (eds.) Territorial Governance across Europe. Pathways, practices and prospects. London and New York, Routledge, pp. 238-253.

Davies H., Edwards D., Hooper A., Punter J., 1989. Planning Control in Western Europe. HMSO, London.

DE Presidency of the European Union, 2007. Territorial Agenda of the European Union: Towards a More Competitive and Sustainable Europe of Diverse Regions.

Doria L., Fedeli V., Tedesco C. (eds.), 2006. Rethinking European spatial policy as a Hologram. Actions, institutions, discourses. Aldershot: Ashgate.

Dühr S., Colomb C., Nadin V., 2010. European Spatial Planning and Territorial Cooperation. London and New York: Routledge.

Dühr S., Stead D., Zonneveld W. (eds.), 2007. The Europeanization of Spatial Planning Through Territorial Cooperation. Planning Practice \& Research, vol. 22, no. 3, pp. 291-471.

ESPON - European Spatial Planning Observation Network, 2007a. ESPON Project 2.3.2. Governance of territorial and urban policies from EU to local level, Final report. ESPON EGTC.

ESPON \& TU Delft, 2018. ESPON COMPASS - Comparative Analysis of Territorial Governance and Spatial Systems in Europe. Final Report. ESPON EGTC.

EU - European Council of the European Union, 2014. Directive 2014/89/EU of the European Parliament and of the Council of 23 July 2014 establishing a framework for maritime spatial planning. Official Journal of the European Union, L257, pp. 135-145.

Faludi A., 2001. European spatial planning: a contested field. Built Environment, vol. 27, no. 4, pp. 245252.

Faludi A., 2018. The Poverty of Territorialism. A Neo-Medieval View of European Spatial Planning. Edgar Elgar.

Faludi A., Waterhout B., 2002. The making of the European spatial development perspective. No masterplan. London and New York: Routledge.

Featherstone K., Radaelli C. M. (eds.), 2003. The Politics of Europeanization. Oxford: Oxford University Press.

Gänzle S., Kern K. (eds.), 2015. A ,macro-regional' Europe in the Making: Theoretical Approaches and Empirical Evidence. Springer.

Hans S., Böhme K., 2018. Planning in Luxembourg: innovation and tradition under one umbrella? Europa XXI, vol. 35, pp. 57-68.

Healey P., Williams, R., 1993. European urban planning systems: Diversity and convergence. Urban Studies, vol. 30, no. 4-5, pp. 701-720.

HU Presidency of the European Union, 2011. Territorial Agenda of the European Union 2020 - Towards an Inclusive, Smart and Sustainable Europe of Diverse Regions. 
Janin Rivolin U., 2008. Conforming and performing planning systems in Europe: An unbearable cohabitation. Planning, Practice \& Research, vol. 23, no. 2, pp. 167-186.

Janin Rivolin U., 2010. EU territorial governance: learning from institutional progress. European Journal of Spatial Development, vol. 38, pp. 1-28.

Janin Rivolin U., 2012. Planning systems as institutional technologies: a proposed conceptualization and the implications for comparison. Planning Practice and Research, vol. 27, no. 1, pp. 63-85.

Jensen O. B., Richardson T., 2001. Nested visions: new rationalities of space in European spatial planning. Regional Studies, vol. 35, no. 8, pp. 703-717.

Knill C., Lehmkuhl D., 1999. How Europe Matters. Different Mechanisms of Europeanization. European Integration Online Papers, vol. 7, no. 3, http://eiop.or.at/eiop/texte/1999-007.htm [12 December 2018].

Komornicki T., Szejgiec-Kolenda B., Degórska B., Goch K., Śleszyński P., Bednarek-Szczepańska M., Siłka P., 2018. Spatial planning determinants of cohesion policy implementation in Polish regions. Europa XXI, vol. 35, pp. 69-88.

Larsson G., 2006. Spatial Planning Systems in Western Europe: An Overview. Amsterdam: IOS Press.

Lenschow A., 2006. Europeanization of public policy. [in:] J. Richardson (ed.) European Union - Power and policy making. Abingdon: Routledge, pp. 55-71.

March J. G., Olsen J. P., 1998. The institutional dynamics of international political orders. International Organization, vol. 52, no. 4, pp. 943-969.

Nadin V. (ed.), 2012. International Comparative Planning Methodology. Planning Practice \& Research, vol. 27, no. 1, pp. 1-154.

Nadin V., Stead D., 2008. European spatial planning systems, social models and learning. disP, vol. 172, no. 1, pp. 35-47.

Newman P., Thornley A., 1996. Urban planning in Europe. London: Routledge.

Nugent N., 2006. The Government and Politics of the European Union. Basingstoke and Durham NC: Palgrave and Duke University Press.

Olsen J. P., 2002. The many faces of Europeanization, Journal of Common Market Studies, vol. 40, no. 5, pp. 921-952.

Othengrafen F., 2010. Spatial planning as expression of culturised planning practices: The examples of Helsinki, Finland and Athens, Greece. Town Planning Review, vol. 81, no. 1, pp. 83-110.

Pámer Z., 2018. How governance counts? Comparative analysis of activity and funding patterns of Central European cross-border cooperation programmes. Europa XXI, vol. 35, pp. 111-126.

Perger É., 2018. Planning and development activities in functional regions - the Hungarian case. Europa XXI, vol. 35, pp. 37-56.

Prezioso M., 2007. Why ESPON Programme is felled as full of policy implications more than scientific suggestions. European Journal of Spatial Development, vol. 4, pp. 1-8.

Purkarthofer E., 2018. Understanding Europeanization from Within. The interpretation, implementation and instrumentalization of European spatial planning in Austria and Finland. Doctoral Dissertations. Aalto University.

Radaelli C. M., 2004. Europeanization: solution or problem? European Integration Online Papers, vol. 8, no. 16, http://eiop.or.at/eiop/texte/2004-016.htm [12 December 2018].

Sassen S., 2006. Migration, citizenship, ethnos. Palgrave Macmillan.

Schimmelfenning F., Sedelmeier U. (eds.), 2005. The Europeanization of central and eastern Europe. Cornell University Press.

Servillo L., 2010. Territorial Cohesion Discourses: Hegemonic Strategic Concepts in European Spatial Planning. Planning Theory and Practice, vol. 11, no. 3, pp. 397-416.

Servillo L., De Bruijn M., 2018. From LEADER to CLLD: The adoption of the new fund opportunities and of their local development options. European Structural and Investment Funds Journal, vol. 3, 223-233.

Smas L., Lidmo J., 2018. Organising regions: spatial planning and territorial governance practices in two Swedish regions. Europa XXI, vol. 35, pp. 21-36.

Stead D., Cotella G., 2011a. Differential Europe. disP, vol. 186, no. 3, pp. 12-83. 
Stead D., Cotella G., 2011b. Spatial planning and the influence of domestic actors. Some conclusions. disP, vol. 186, no. 3, pp. 77-83.

Swyngedouw E., 2000. Authoritarian governance, power, and the politics of rescaling. Environment and planning D: Society and space, vol. 18, no. 1, pp. 63-76.

Valkenburg G., Cotella G., 2016. Governance of energy transitions: about inclusion and closure in complex sociotechnical problems. Energy, Sustainability and Society, vol. 6, no. 20.

Vedung E., Rist R. C., Bemelmans-Videc M. L. (eds.), 1998. Carrots, sticks \& sermons: policy instruments and their evaluation. Transaction Publishers.

Walsh C., Kannen A., 2019. Planning at Sea: Shifting Planning Practices at the German North Sea Coast. Raumforschung und Raumordnung, Spatial Research and Planning, vol. 77, no. 1, pp. 1-18.

Waterhout B., 2008. The institutionalisation of European spatial planning. vol. 18, IOS Press.

Williams B., Varghese J., 2018. Examining the impact of EU cohesion policies aiming to reduce regional and social disparities with examples of policy impacts in Ireland. Europa XXI, vol. 35, pp. 89-110.

Williams M. D., Williams R. H., 1996. European Union spatial policy and planning. SAGE.

Wishlade F., Yuill D., Mkendez C., 2003. Regional policy in the EU: a passing phase of Europeanisation or a complex case of policy transfer? University of Strathclyde, European Policies Research Centre.

Zaucha J., 2018. Book Review: The Poverty of Territorialism. A Neo-Medieval View of European Spatial Planning. Europa XXI, vol. 35, pp. 127-132. 